\title{
Structural Behavior of Precast Lightweight Foam Concrete Sandwich Panel with Double Shear Truss Connectors under Flexural Load
}

\author{
Noridah Mohamad, A. I. Khalil, A. A. Abdul Samad, and W. I. Goh \\ Department of Civil \& Material Engineering, Faculty of Civil and Environmental Engineering, \\ Universiti Tun Hussein Onn, Batu Pahat, Johor, 86400 Parit Raja, Malaysia \\ Correspondence should be addressed to Noridah Mohamad; noridah@uthm.edu.my
}

Received 13 September 2013; Accepted 18 November 2013; Published 16 March 2014

Academic Editors: P. Qiao and I. G. Raftoyiannis

Copyright (C) 2014 Noridah Mohamad et al. This is an open access article distributed under the Creative Commons Attribution License, which permits unrestricted use, distribution, and reproduction in any medium, provided the original work is properly cited.

\begin{abstract}
This paper presents the structural behaviour of precast lightweight foam concrete sandwich panel (PFLP) under flexure, studied experimentally and theoretically. Four (4) full scale specimens with a double shear steel connector of 6 mm diameter and steel reinforcement of $9 \mathrm{~mm}$ diameter were cast and tested. The panel's structural behavior was studied in the context of its ultimate flexure load, crack pattern, load-deflection profile, and efficiency of shear connectors. Results showed that the ultimate flexure load obtained from the experiment is influenced by the panel's compressive strength and thickness. The crack pattern recorded in each panel showed the emergence of initial cracks at the midspan which later spread toward the left and right zones of the slab. The theoretical ultimate load for fully composite and noncomposite panels was obtained from the classical equations. All panel specimens were found to behave in a partially composite manner. Panels PLFP-3 and PLFP-4 with higher compressive strength and total thickness managed to obtain a higher degree of compositeness which is 30 and 32.6 percent, respectively.
\end{abstract}

\section{Introduction}

A sandwich panel is a three or more layer element, usually comprising of thin faces/wythes of high-strength material which encloses a thicker inner layer of low average strength. Such sandwich structures have gained widespread acceptance within the aerospace, naval/marine, automotive, and general transportation industries as an excellent way to obtain extremely lightweight components and structures with very high bending stiffness, high strength, and high buckling resistance $[1,2]$. Precast lightweight foam concrete sandwich panel (PLFP) consists of two wythe layers of reinforced lightweight foamed concrete with polystyrene as an insulation layer. The layers are bonded by double shear connectors which are embedded through it diagonally as illustrated in Figures 1 and 2. The double shear connectors' function is to transfer the load applied between the wythes. The degree of compositeness of the wall panel is influenced by the effectiveness of these shear connectors [3].
Precast concrete system made from conventional concrete has been developed and introduced into the construction industry and since then has continued to grow in importance. Benayoune et al. have proven in their study that the sandwich precast system which used conventional concrete as faces and polystyrene as core layer behaved in a partial composite behavior. It was also found that all test specimens proved to be ductile, exhibiting large deformation prior to failure [4]. However, conventional concrete has low strength to weight ratio which results in a longer construction period and more workers during the construction process. As such, this study proposes the use of a PLFP sandwich panel which uses the foamed concrete as its wythe. This new precast system is lighter but higher in strength to weight ratio.

Foamed concrete is defined as a cementitious material with a minimum of $20 \%$ (per volume) foam entrained into the plastic mortar. It is produced by entrapping numerous small bubbles of air in the cement paste or mortar. The most common used foam concentrates are based on protein 
TABLE 1: Details and dimensions of PLFP specimens.

\begin{tabular}{|c|c|c|c|c|c|c|c|c|}
\hline Panel & $H \times W \times t(\mathrm{~mm})$ & $(H / t)$ & $t_{1}$ & $t_{2}$ & $C$ & $\begin{array}{c}\text { Reinforcement } \\
\text { (vertical and horizontal, } \\
\text { top and bottom) }\end{array}$ & $\mathrm{D}$ & $\begin{array}{l}\text { Density of foamed concrete } \\
\qquad \mathrm{Kg} / \mathrm{m}^{3}\end{array}$ \\
\hline PLFP-1 & $2000 \times 750 \times 100$ & 20 & 40 & 20 & $15 \mathrm{~mm}$ & $\begin{array}{c}9 \mathrm{~mm} \Phi \\
\text { at } 300 \mathrm{~mm} \mathrm{c} / \mathrm{c}\end{array}$ & R6 & 1800 \\
\hline PLFP-2 & $2000 \times 750 \times 100$ & 20 & 40 & 20 & $15 \mathrm{~mm}$ & $\begin{array}{l}9 \mathrm{~mm} \Phi \\
\text { at } 300 \mathrm{~mm} \mathrm{c} / \mathrm{c}\end{array}$ & R6 & 1800 \\
\hline PLFP-3 & $2000 \times 750 \times 110$ & 18.18 & 40 & 30 & $15 \mathrm{~mm}$ & $\begin{array}{c}9 \mathrm{~mm} \Phi \\
\text { at } 300 \mathrm{~mm} \mathrm{c} / \mathrm{c}\end{array}$ & R6 & 1800 \\
\hline PLFP-4 & $2000 \times 750 \times 110$ & 18.18 & 40 & 30 & $15 \mathrm{~mm}$ & $\begin{array}{l}9 \mathrm{~mm} \Phi \\
\text { at } 300 \mathrm{~mm} \mathrm{c} / \mathrm{c}\end{array}$ & R6 & 1800 \\
\hline
\end{tabular}

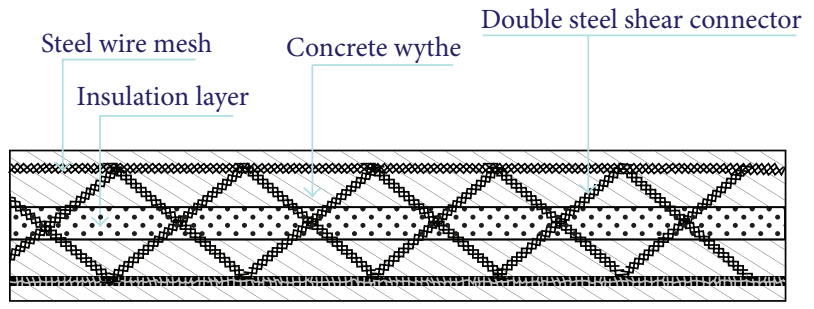

Figure 1: Precast lightweight foamed concrete sandwich panel (PLFP) with double shear truss connectors.

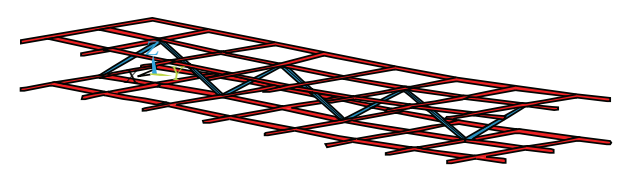

FIGURE 2: The orientation of steel reinforcement and shear connectors in PLFP.

hydrolyzates or synthetic surfactants. They are formulated to produce air bubbles that are stable and able to resist the physical and chemical forces imposed during mixing, placing, and hardening $[5,6]$.

This research investigated the structural behavior of the PLFP panel with double shear connectors subjected to flexure load. It focused on ultimate strength capacity of the panel under flexure load and the efficiency of the double shear connector for precast lightweight foam concrete sandwich panel under the applied load.

\section{Experimental Study}

Four (4) full scaled PLFP specimens with similar width $(750 \mathrm{~mm})$, height $(2000 \mathrm{~mm})$, and various thicknesses are listed in Table 1 . Concrete cover of $15 \mathrm{~mm}$ was used and the thickness of each concrete wythe was fixed at $40 \mathrm{~mm}$ for all panels as it is the minimum cover and thickness required to meet the durability and fire resistance requirements according to BS 8110. The aspect ratio, $1 / \mathrm{w}$, was fixed at 2.67. The PLFP specimens were tested under flexure load till failure. The details of the specimen's dimension and design are illustrated in Figure 3.
2.1. Material Properties. The materials used for casting the specimen were concrete, foamed concrete, steel bars ( $9 \mathrm{~mm})$, steel truss connectors $(6 \mathrm{~mm})$, and polystyrene. The concrete was used as capping with thickness of $100 \mathrm{~mm}$ at both ends of the panel specimen. Materials for capping were Portland cement, aggregate, sand, steel bars, and polystyrene. The ratio used for cement: aggregate: sand is $1: 2: 4$ with foam cement ratio of 0.65 and water cement ratio of 0.5 . The materials used in foamed concrete are foam, cement, fine sand and water. The foam was produced by mixing one part of foam agent (in liquid form) to forty parts of water in the foam mixer. The cement used was Portland cement and the sand used was sieved through $2.5 \mathrm{~mm}$. The ratio of cement: sand was $1: 2$ with water to cement ratio of 0.55 . The foam was added gradually in stages until the targeted wet density (1700 to $1800 \mathrm{~kg} / \mathrm{m}^{3}$ ) was achieved, aiming for compressive strength of $15 \mathrm{MPa}$. The polystyrene was cut into pieces and inserted in between the foamed concrete layers. The properties for steel reinforcement and truss connectors are shown in Table 2.

2.2. Fabrication and Casting. The specimen was cast horizontally using steel formwork. Space blocks were used to maintain the concrete cover at $15 \mathrm{~mm}$. Concrete was poured first as the capping at both ends of the specimen. The horizontal and longitudinal steel bars tied with double shear truss connectors were placed in the formwork. The shear connectors were bent at 45 degrees. The bottom layer of foamed concrete was then poured into the formwork. Polystyrene was cut into pieces and inserted in between the steel bars and truss connectors. Finally, the upper layer was poured on top of the core layer and trowel to obtain a smooth surface.

2.3. Test Set-Up and Procedure. The PLFP panels were tested in a universal testing machine of $1000 \mathrm{kN}$ capacity in a horizontal position. The panels were simply supported and subjected to two-line flexural loads. The force introduced to the load cell was generated by a hydraulic pump. The force was transferred through the I-beams to the panel. The test set-up is illustrated in Figure 4.

A total of 12 strain gauges of size $30 \mathrm{~mm}$ were used to measure the strain across the depth in each panel. The strain gauges (SG1 to SG10) were placed on the surface and across the thickness at the midspan of panel. The locations of the strain gauges are illustrated in Figure 5. Linear Voltage 


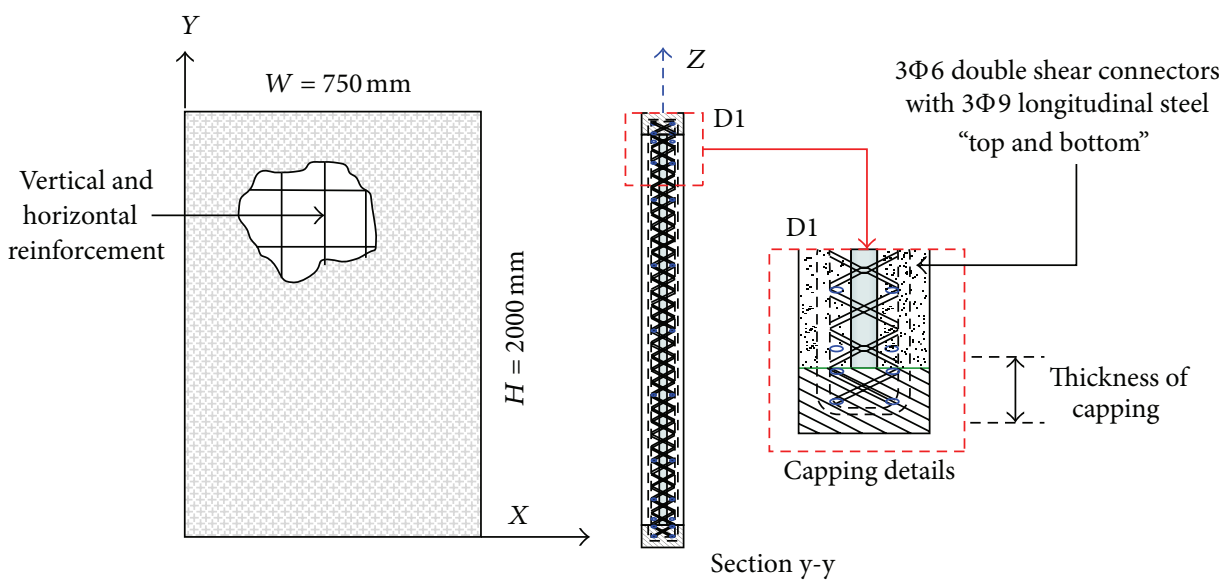

FIGURE 3: Dimension and details of the panels.

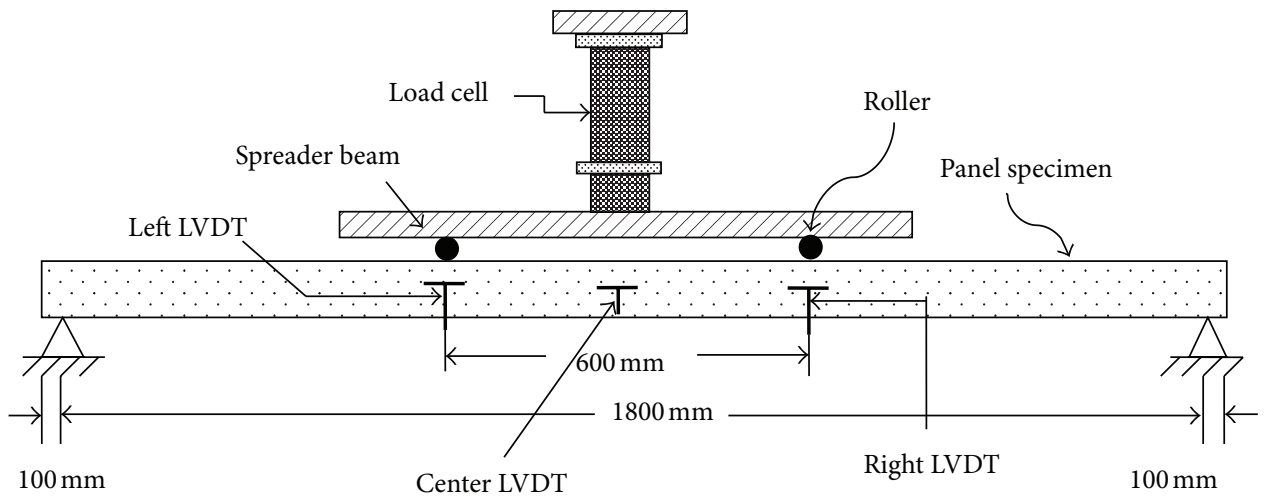

FIgURE 4: Test set-up of panel specimen.

Displacement Transducer (LVDT) was used to measure the deflection. The locations of the LVDT are shown in Figure 4.

The panel was placed carefully in the frame with simply supported condition. A small load of $1 \mathrm{kN}$ was first applied to make sure that all the instruments were working. At each load stage, strains on the surface and across the thickness of the concrete were recorded automatically using a computerized data acquisition system. The crack pattern was also noted at each load stage. Cracks were marked on the surface of the specimen indicating the corresponding load.

\section{Results and Discussion}

The data are analysed from the results of ultimate flexure load achieved, crack pattern, load-deflection profiles, and the efficiency of shear connectors.

3.1. Ultimate Flexure Load. Table 3 shows the ultimate flexural load recorded for each panel. The aspect ratio of each panel was fixed at 2.67. It is observed that the ultimate strength achieved in the PLFP panels did not depend on any one factor alone; instead, there are two significant factors which contribute to the panel's strength capacity, namely, its compressive strength and total thickness. From the results,

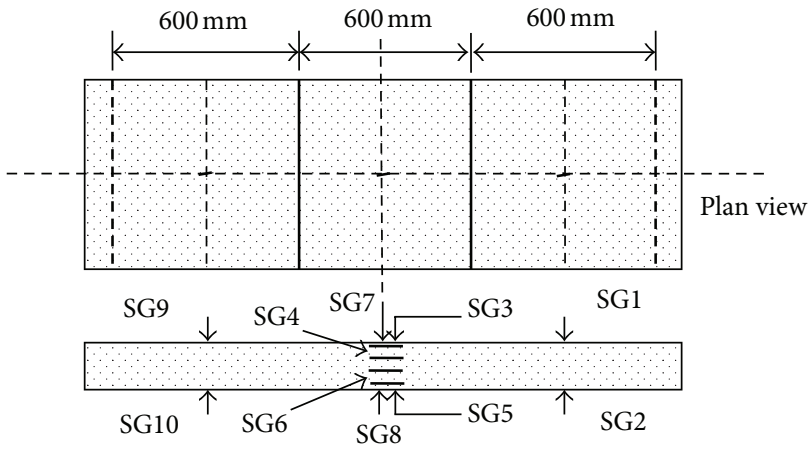

FIGURE 5: Location of strain gauges on the surface and across the thickness of panel.

it can be seen that compressive strength has a significant effect on the ultimate load achieved. The effect of panel's thickness on the ultimate load cannot really be concluded since panels with different thicknesses also have different compressive strengths. Panel PLFP-3 and PLFP-4 have similar total thickness but a slightly different compressive strength. Panel PLFP-4 recorded a higher ultimate flexural load. 
TABLE 2: Properties of steel.

\begin{tabular}{lcccc}
\hline Steel & Yield stress $\sigma_{y}(\mathrm{MPa})$ & Tensile strength $\sigma_{t}(\mathrm{MPa})$ & Strain at failure & $E_{S}\left(\mathrm{kN} / \mathrm{mm}^{2}\right)$ \\
\hline $6 \mathrm{~mm}$ truss connector bars & 518 & 544.28 & 0.0478 & 197.8 \\
$9 \mathrm{~mm}$ truss connector bars & 559 & 626.5 & 0.1934 & 203.68 \\
\hline
\end{tabular}

TABLE 3: Ultimate flexural load.

\begin{tabular}{lcccc}
\hline Specimen & Total thickness $(\mathrm{mm})$ & Aspect ratio $l / b$ & Compressive strength $\left(\mathrm{N} / \mathrm{mm}^{2}\right)$ & Ultimate load $(\mathrm{kN})$ \\
\hline PLFP-1 & 100 & 2.67 & 4.7 & 10.83 \\
PLFP-2 & 100 & 2.67 & 10.6 & 8.23 \\
PLFP-3 & 110 & 2.67 & 18 & 24.03 \\
PLFP-4 & 110 & 2.67 & 19 & 25.63 \\
\hline
\end{tabular}

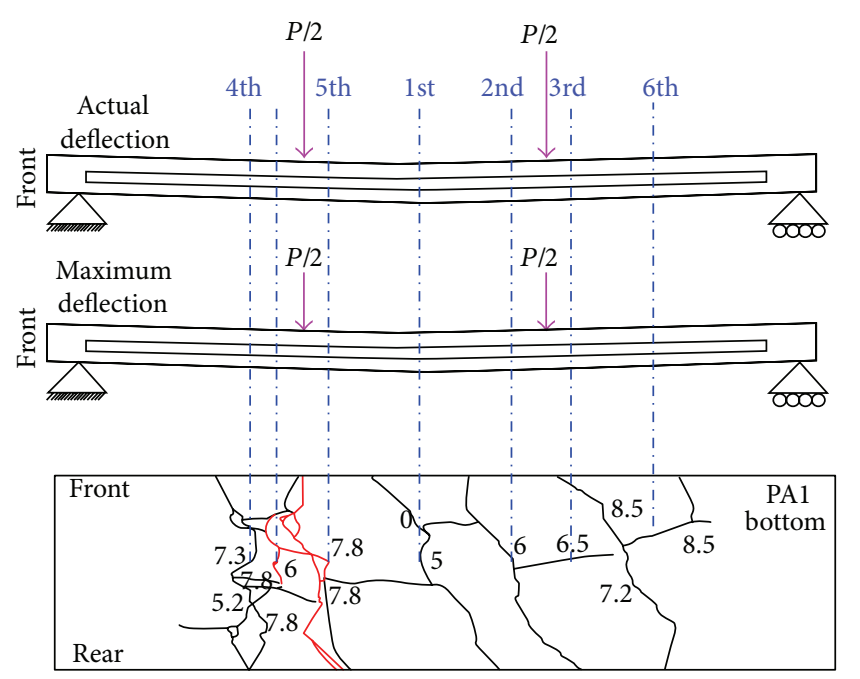

- Major cracks
Minor cracks

FiguRE 6: Crack pattern of panel PLFP-1.

3.2. Crack Pattern. In general, the crack pattern recorded in each panel showed the emergence of cracks at the midspan and later spread toward the left and right zones of the slab. The crack pattern for panel PLFP-1 is discussed here because it is the most fragile panel with the lowest ultimate load achieved. It is found that that the first crack occurred at load $5 \mathrm{kN}$ and second crack, 2nd, and third crack, 3rd, appeared almost simultaneously at a load of about $6 \mathrm{kN}$, while fourth and fifth crack, 4th and 5th, occurred at a load of about $7.3 \mathrm{kN}$ and $7.8 \mathrm{kN}$, respectively, as shown in Figure 6. Finally, crack 6th appeared at a load of about $8.5 \mathrm{kN}$ and became the failure crack. The opening process of crack 3 and 4 developed simultaneously reaching a maximum value of $5 \mathrm{~mm}$ at the panel's bottom surface. Maximum deflection at failure load was recorded at $20.42 \mathrm{~mm}$.

3.3. Load-Deflection Profile. Figure 7 shows the loaddeflection profiles recorded from right, left, and center LVDT for panels PLFP-1 to PLFP-4. It is seen that before
TABLE 4: Maximum deflection in each panel.

\begin{tabular}{lccc}
\hline Specimen & $\begin{array}{c}\text { Ultimate load } \\
(\mathrm{kN})\end{array}$ & $\begin{array}{c}\text { Maximum } \\
\text { deflection }(\mathrm{mm})\end{array}$ & $\begin{array}{c}\text { Frist crack load } \\
(\mathrm{kN})\end{array}$ \\
\hline PLFP-1 & 10.8 & 9.1 & 5 \\
PLFP-2 & 8.2 & 13.9 & 3.2 \\
PLFP-3 & 24 & 24.1 & 9 \\
PLFP-4 & 25.6 & 22.1 & 5.1 \\
\hline
\end{tabular}

the first crack in the concrete appeared, the panels deflected elastically and therefore the load-deflection curves were approximately linear. However, after cracking, the loaddeflection curve became nonlinear and the deflections increased significantly till failure. Table 4 shows the ultimate load and maximum deflection in each panel. The maximum deflection of $24.1 \mathrm{~mm}$ occurred in Panel PLFP-3. Maximum ultimate load of $25.6 \mathrm{kN}$ was recorded in panel PLFP-4. All maximum deflections occurred at the midspan of panel because this is the critical area where the maximum deflection was expected [7-9]. The figure also illustrates the expected behavior in all panels with a significant difference in the maximum load and deflection achieved between the panels PLFP-1 and PLFP-2 and panels PLFP-3 and PLFP-4.

3.4. Efficiency of Shear Connectors. The efficiency of shear connectors in this study was measured by the strain distribution across the panel's thickness at midspan. The pattern of the distribution curve was analyzed to estimate the composite action achieved by different layers in the sandwich panel. The degree of compositeness was also estimated by using the equation for theoretical ultimate load for full and noncomposite sandwich panels [10].

3.4.1. Strain Distribution across Panel's Thickness at Midspan. The strain distributions across the thickness of the panel at midspan for PLFP-4 at different load stages are shown in Figure 8. It is noticed that the small discontinuity of strain across the depth is relatively small at the initial load stages. However, the discontinuity becomes larger with the loading approaching the failure load. 

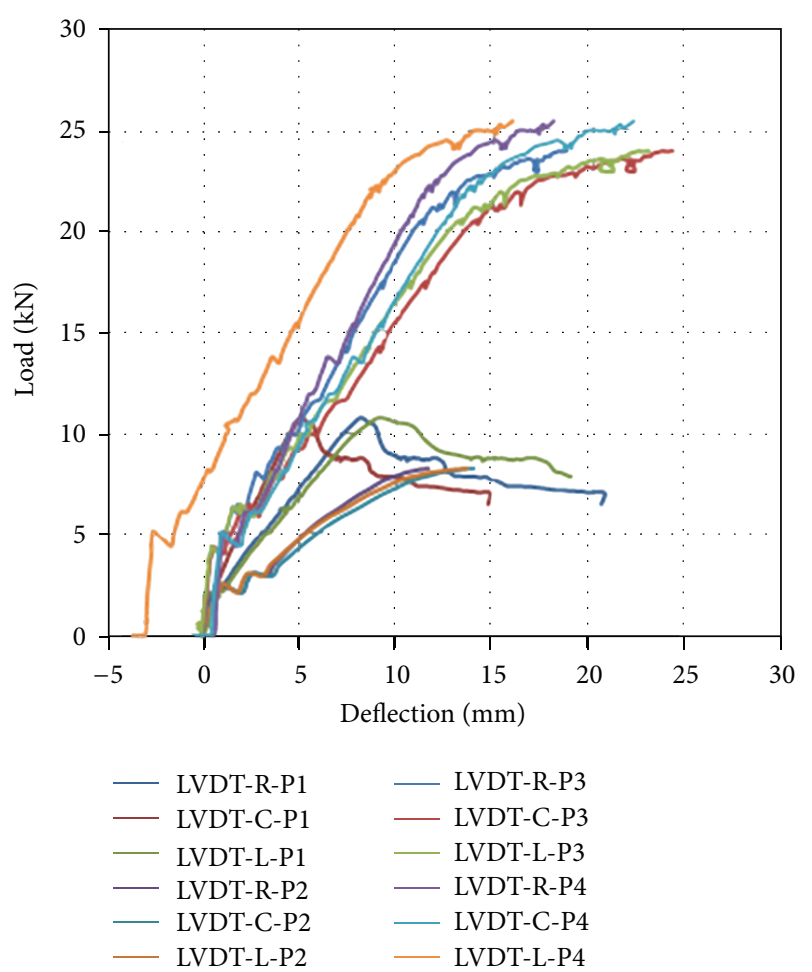

FIGURE 7: Load-deflection profiles for panels PLFP-1 to PLFP-4.

From the strain distribution across the depth of the panel, it is seen that the panel behaved in a partial composite behavior. It indicates that the shear connector provided was not fully efficient in transferring the applied load. The inefficiency of the shear connector could be due to an improper connection between the shear connectors and imperfection during placement for testing. This efficiency has resulted in the shear connector's function to connect all three layers in PLFP panel and enabling them to act as a single unit. Furthermore, the number of shear connector may not be enough to make the panel fully composite. From the discontinuity in the strain distribution across the depth, it is shown that all the panels have obtained partial composite behavior.

\subsubsection{Theoretical Ultimate Load for Full and Noncomposite} Sandwich Panels. Depending on the degree of composite action achieved, a PLFP may be regarded as a fully composite, semicomposite, or noncomposite panel. In a composite panel, the two concrete wythes act together as a single unit to resist applied loads till failure. This is accomplished by providing a full shear transfer between the two wythes. A fully composite panel fails either by concrete crushing or steel reinforcement yielding without failure of the connectors. In a noncomposite panel, the two wythes act independently. In a partially composite panel, the connectors can transfer only a fraction of the longitudinal shear as required for a fully composite action. In this case, the connectors fail before concrete crushing or yielding of the reinforcement [11].

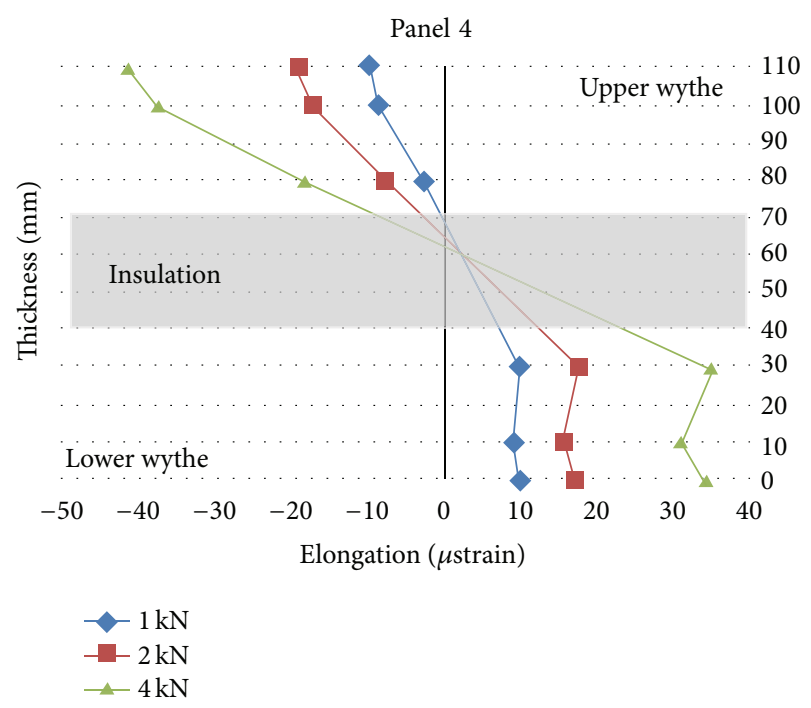

FIGURE 8: Strain distribution across thickness of panel PLFP-4.

The calculations were performed at the ultimate strength of panels to estimate its composite action. The ultimate flexural strength of the PLFP by classical method is not possible to be assessed as the degree of composite action between the two wythes is not known and its influence on the transverse load carrying capacity could not be incorporated. However, at the two extremes of composite action, the calculation of the ultimate load of a fully composite and noncomposite action can be carried out.

The degree of composite action at ultimate stage is determined by using the method described below. When no composite action is assumed at ultimate strength (Figure 9(a)), the ultimate flexural capacity of the panel would be calculated as follows:

$$
\begin{gathered}
F_{s_{1}}=A_{s} f_{y}, \\
F_{c_{1}}=0: 85 f_{c u} b s_{1},
\end{gathered}
$$

where $A_{s}=$ area of tension reinforcement, $b=$ per meter length of wall section or the connectors spacing, $F_{c_{1}}=$ compressive force in concrete (noncomposite), $F_{s_{1}}=$ force in tension reinforcement (noncomposite), $f_{y}=$ yield stress of steel, $s_{1}=0.9 x$, depth of neutral axis.

At equilibrium,

$$
\begin{aligned}
& F_{s_{1}}=F_{c_{1}}, \\
& s_{1}=\frac{F_{s_{1}}}{F_{c_{1}}} .
\end{aligned}
$$

When the panel is assumed to be fully composite at ultimate strength (Figure 9(b)), the ultimate flexural capacity of the panel would be calculated as follows:

$$
\mathrm{Mu}=T\left(d-\frac{s}{2}\right)
$$

where $d=$ depth of the reinforcement as shown in Figure $9, F_{c}=$ compressive force in concrete, $\mathrm{Mu}=$ ultimate 
TABLE 5: Ultimate flexure load.

\begin{tabular}{lcccc}
\hline \multirow{2}{*}{ Specimen } & \multirow{2}{*}{ Ultimate load $(\mathrm{kN})$} & Cully composite & Noncomposite & Degree of compositeness \\
\hline PLFP-1 & 10.8 & 43.6 & 7.32 & 9.6 \\
PLFP-2 & 8.2 & 53 & 4.1 & 8.4 \\
PLFP-3 & 24 & 56 & 10.24 & 30 \\
PLFP-4 & 25.6 & 56.4 & 10.72 & 32.6 \\
\hline
\end{tabular}

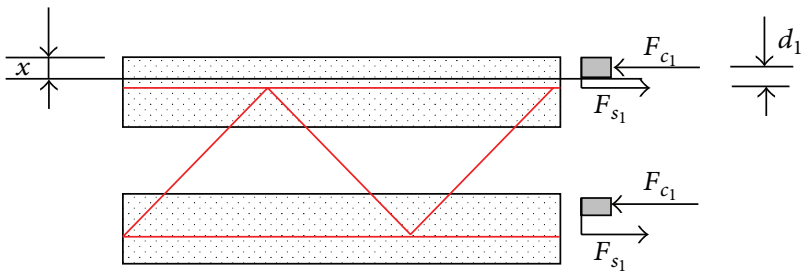

(a) Noncomposite action (1 meter length)

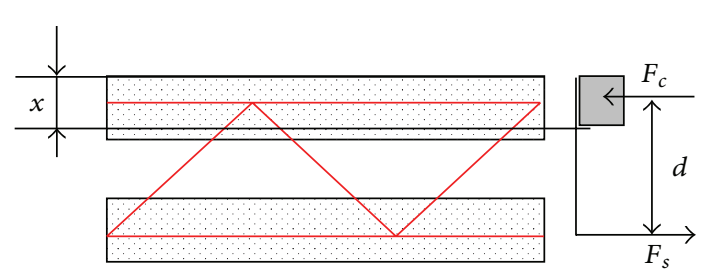

(b) Fully composite action (1 meter length)

FIgURE 9: Noncomposite and fully composite panels.

moment capacity under flexure, $s=0.9 x$, depth of neutral axis measured from the more highly compressed face, $F s=$ force in tension reinforcement.

The values of ultimate flexure load obtained from experiment and theoretical formulae are listed in Table 5. The experimental ultimate load for all panels is in between the ultimate load for fully composite and noncomposite panels. However, panels PLFP-3 and PLFP-4 with higher compressive strength and total thickness managed to obtain a higher degree of compositeness which is 30 and 60 percent, respectively.

\section{Conclusions}

(i) The ultimate load increases with the increase of the thickness split tensile strength and compressive strength of foamed concrete. The ultimate flexure load was recorded at $10.8 \mathrm{kN}$ and $8.2 \mathrm{kN}$ for PLFP-1 and PLFP-2, respectively, and $24 \mathrm{kN}$ and $25.6 \mathrm{kN}$ for PLFP-3 and PLFP-4 with higher compressive strength and total thickness.

(ii) Cracks were observed at the bottom wythe of the PLFP panels. Most panels finally failed by crushing of concrete. The first crack occurred at $40 \%$ to $80 \%$ of the ultimate load. The cracks did not occur at the area of the joint between normal concrete capping and foam concrete wythes.

(iii) From the results of the theoretical flexure load for full and noncomposite, all PLFP panels were found to behave as partially composite structures. Panels PLFP-3 and PLFP-4 recorded a higher degree of composite action compared to panels PLFP-1 and PLFP-2.

\section{Conflict of Interests}

The authors declare that there is no conflict of interests regarding the publication of this paper.

\section{Acknowledgments}

The authors would like to thank Universiti Tun Hussein Onn Malaysia and Ministry of Higher Education for their financial support (FRGS-0826).

\section{References}

[1] H. Mahfuz, S. I. Muhammad, K. R. Vijaya, C. S. Mrinal, and J. Shaik, "Response of sandwich composites with nanophased cores under flexural loading," Composites B, vol. 35, no. 6-8, pp. 543-550, 2004.

[2] S. Liang and H. L. Chen, "Investigation on the square cell honeycomb structures under axial loading," Composite Structures, vol. 72, no. 4, pp. 446-454, 2006.

[3] M. Al-Kashif, M. Abdel-Mooty, E. Fahmy, M. Abou Zeid, and M. Haroun, "Nonlinear modeling and analysis of AAC infilled sandwich panels for out of plane loads," World Academy of Science, Engineering and Technology, vol. 64, pp. 597-601, 2012.

[4] A. A. Benayoune, D. N. Abdul Samad, A. A. Trikha, A. Abang, and S. H. M. Ellinna, Flexural Behaviour of Pre-Cast Concrete Sandwich Composite Panel-Experimental and Theoritical Investigations, Elsevier, London, UK, 2008.

[5] British Cement Association, Foamed Concrete Composition and Properties, British Cement Association, 1994.

[6] B. Hilgeman, "Production of precast concrete insulated sandwich wall panels," PCI Journal, vol. 42, no. 2, pp. 128-134, 1997.

[7] N. Mohamad and N. Hassan, "The structural performance of precast lightweight foam concrete sandwich panel with single and double shear truss connectors subjected to axial load," 
Journal of Advanced Materials Research, vol. 634-638, pp. 27462751, 2013.

[8] N. Mohamad and M. H. Mahdi, "Testing of precast lightweight foamed concrete sandwich panel with single and double symmetrical shear truss connectors under eccentric loading," Advanced Materials Research, vol. 335-336, pp. 1107-1116, 2011.

[9] N. Mohamad, W. Omar, and R. Abdullah, "Precast Lightweight Foamed Concrete Sandwich Panel (PLFP) tested under axial load: preliminary results," Advanced Materials Research, vol. 250-253, pp. 1153-1162, 2011.

[10] Designer Notebook, High Performance Precast Insulated Sandwich Wall Panels, 2011.

[11] C. A. Shutt, "Report codifies, details sandwich wall panels," Ascent Journal, pp. 28-33, 1997. 

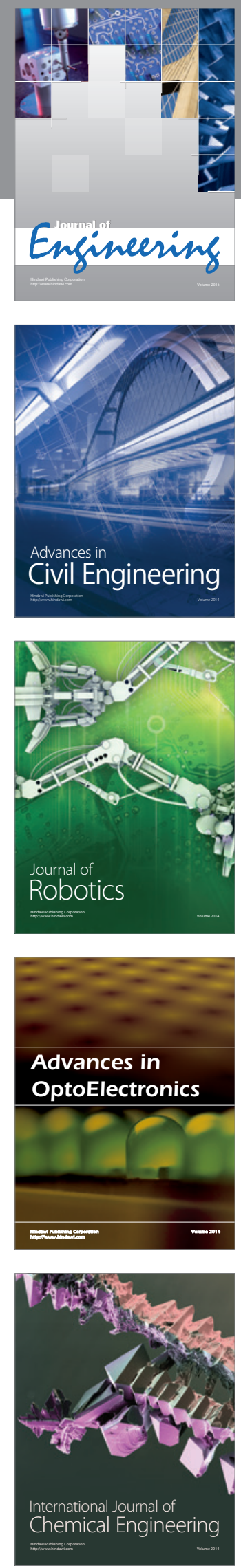

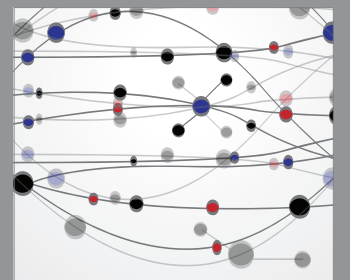

The Scientific World Journal
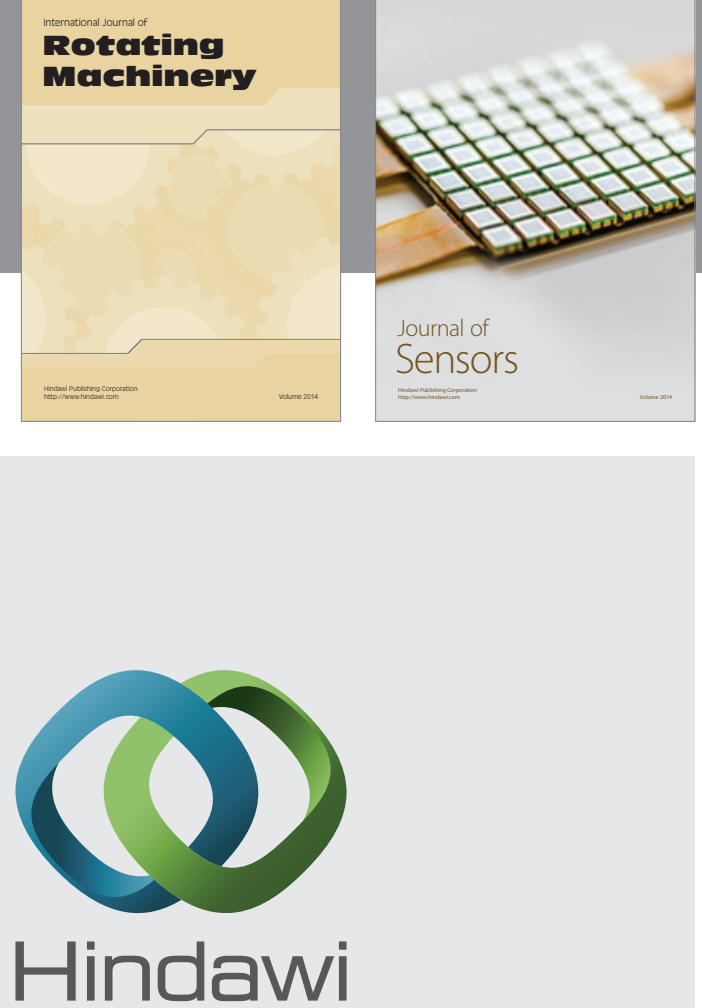

Submit your manuscripts at http://www.hindawi.com
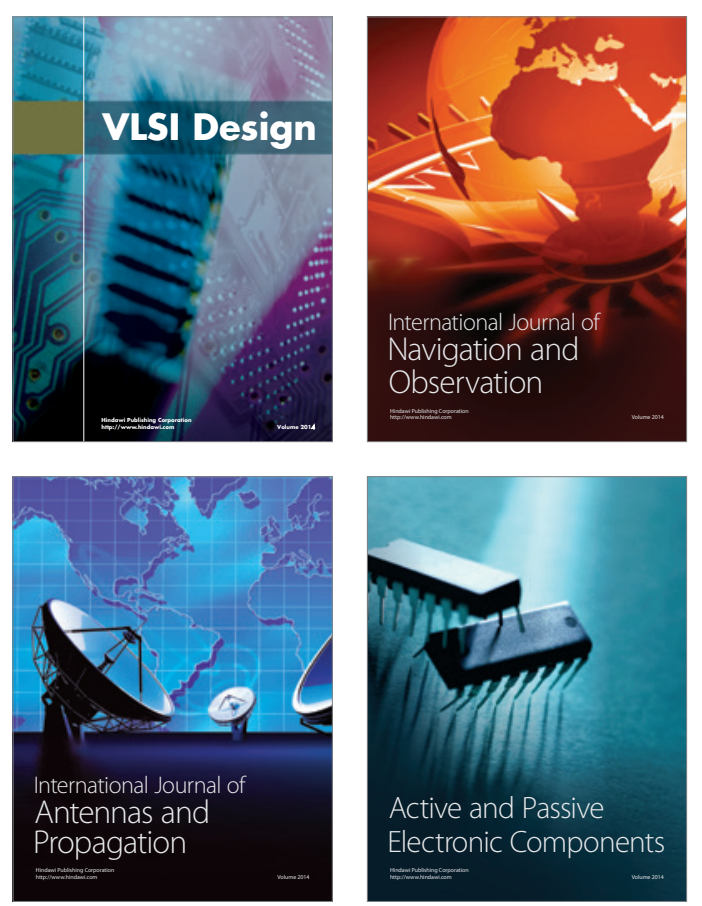
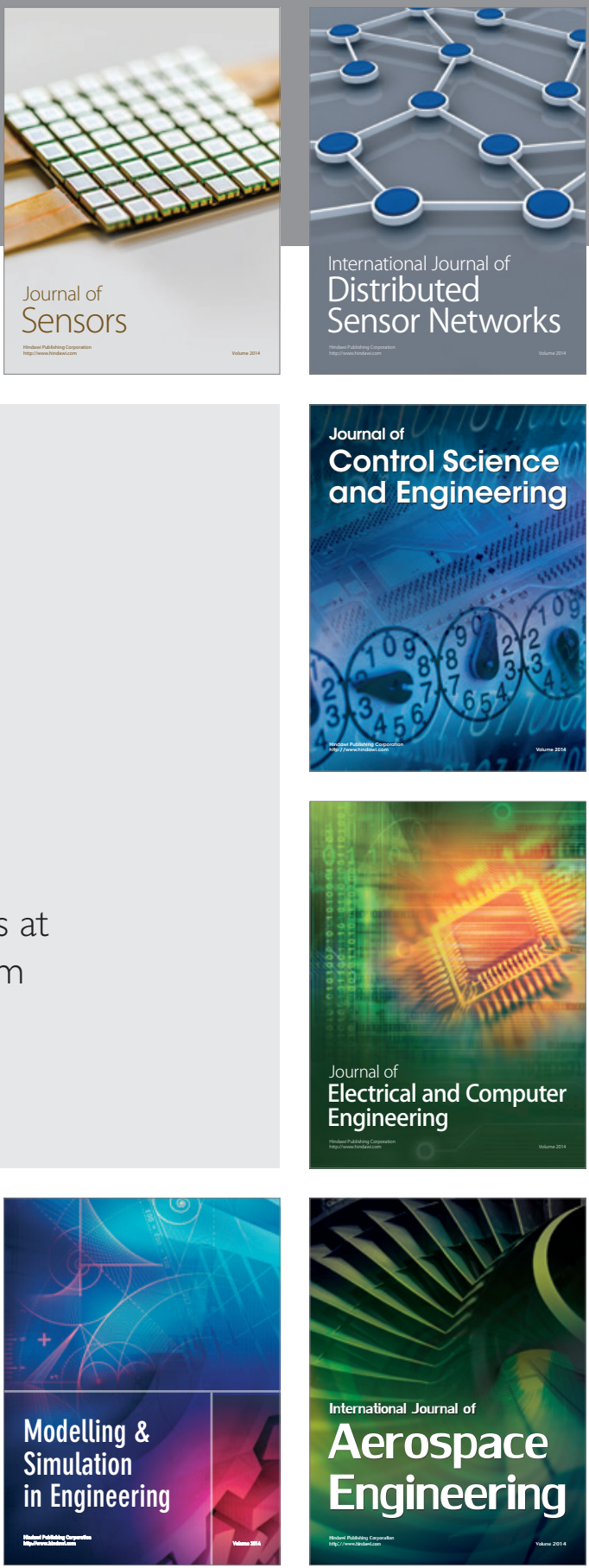

Journal of

Control Science

and Engineering
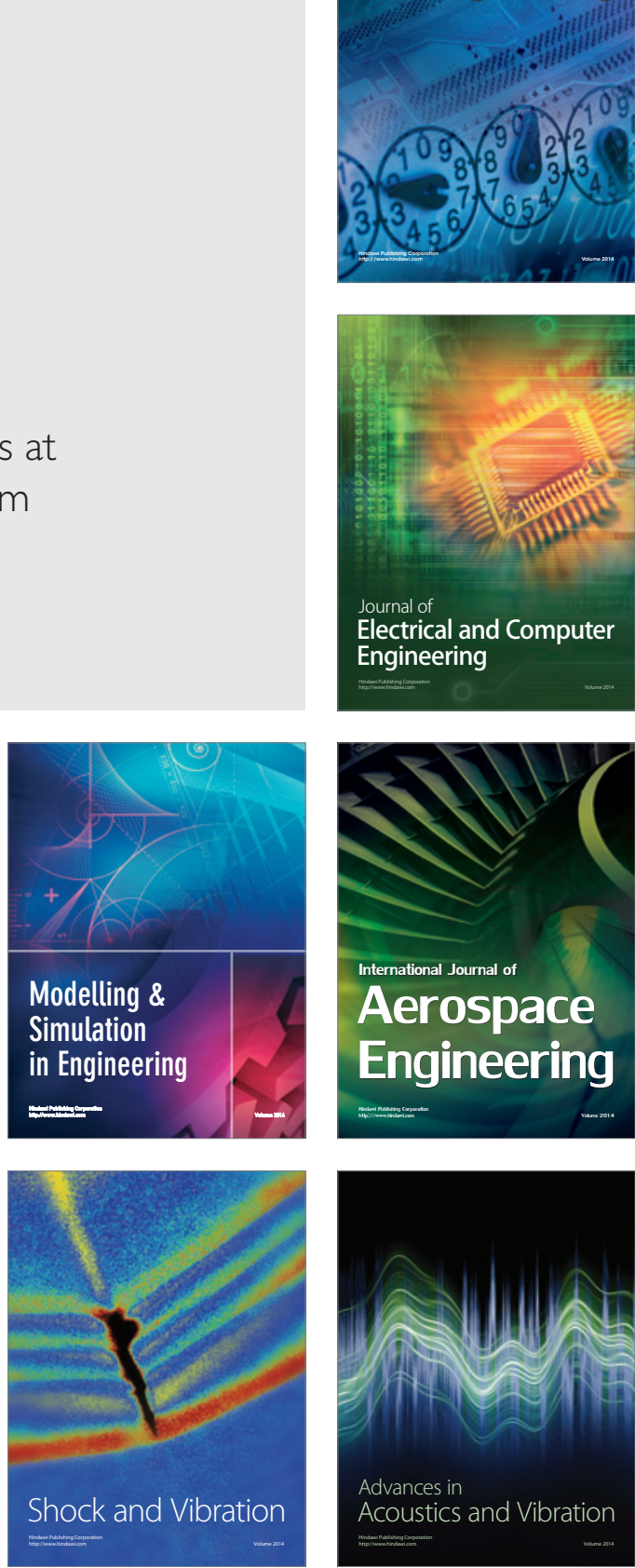